\title{
Cholesterol-enriched diet causes age-related macular degeneration-like pathology in rabbit retina
}

\author{
Bhanu Dasari ${ }^{1}$, Jaya RP Prasanthi ${ }^{1}$, Gurdeep Marwarha ${ }^{1}$, Brij B Singh ${ }^{2}$ and Othman Ghribi ${ }^{1 *}$
}

\begin{abstract}
Background: Alzheimer's disease (AD) and age-related macular degeneration (AMD) share several pathological hallmarks including $\beta$-amyloid (AB) accumulation, oxidative stress, and apoptotic cell death. The causes of AD and AMD are likely multi-factorial with several factors such as diet, environment, and genetic susceptibility participating in the pathogenesis of these diseases. Epidemiological studies correlated high plasma cholesterol levels with high incidence of $A D$, and feeding rabbits with a diet rich in cholesterol has been shown to induce AD-like pathology in rabbit brain. High intake of cholesterol and saturated fat were also long been suspected to increase the risk for AMD. However, the extent to which cholesterol-enriched diet may also cause AMD-like features in rabbit retinas is not well known.
\end{abstract}

Methods: Male New Zealand white rabbits were fed normal chow or a $2 \%$ cholesterol-enriched diet for 12 weeks. At necropsy, animals were perfused with Dulbecco's phosphate-buffered saline and the eyes were promptly removed. One eye of each animal was used for immunohistochemistry and retina dissected from the other eye was used for Western blot, ELISA assays, spectrophotometry and mass spectrometry analyses.

Results: Increased levels of $A \beta$, decreased levels of the anti-apoptotic protein $\mathrm{BCl}-2$, increased levels of the proapoptotic Bax and gadd153 proteins, emergence of TUNEL-positive cells, and increased generation of reactive oxygen species were found in retinas from cholesterol-fed compared to normal chow-fed rabbits. Additionally, astrogliosis, drusen-like debris and cholesterol accumulations in retinas from cholesterol-fed rabbits were observed. As several lines of evidence suggest that oxidized cholesterol metabolites (oxysterols) may be the link by which cholesterol contributes to the pathogenesis of AMD, we determined levels of oxysterols and found a dramatic increase in levels of oxysterols in retinas from cholesterol-fed rabbits.

Conclusions: Our results suggest that cholesterol-enriched diets cause retinal degeneration that is relevant to AMD. Furthermore, our data suggests high cholesterol levels and subsequent increase in the cholesterol metabolites as potential culprits to AMD.

\section{Background}

Age-related macular degeneration (AMD) is a retinal degenerative disease that involves photoreceptors, retinal pigment epithelium (RPE), Bruch's membrane, and choriocapillaris. Drusen, extracellular deposits located between the RPE and Bruch's membrane, are a major hallmark of AMD [1,2]. Drusen contains histochemically detectable lipid including cholesterol in unesterified and esterified forms [3]. In addition to drusen deposits, oxidative stress,

\footnotetext{
* Correspondence: othman.ghribi@med.und.edu

'Department of Pharmacology, Physiology and Therapeutics, University of North Dakota School of Medicine and Health Sciences, Grand Forks, North Dakota, 58202, USA

Full list of author information is available at the end of the article
}

apoptosis and accumulation of $\beta$-amyloid peptide are also hallmarks of AMD [4]. Interestingly, these hallmarks are also characteristics of Alzheimer's disease (AD) [5,6]. Furthermore, $A \beta$ accumulation is the leading neuropathological change that correlates with the diagnosis of $\mathrm{AD}$, and is considered a key player in the pathogenesis of $A D$ by inducing oxidative stress and apoptotic cell death. $A \beta$ levels are regulated by generation from amyloid precursor protein (APP) upon initial cleavage by Beta-secretase 1 (BACE-1) and degradation by enzymes that include insulin-degrading enzyme (IDE). $A \beta$ accumulation has also been shown to be associated with drusen in eyes from AMD patients [7-9] as well as mice models for AMD [10]

\section{Biomed Central}


and $\mathrm{A} \beta$ immunization has been considered a pertinent therapeutic approach for both AD and AMD [11].

There is increasing evidence of a link between AD and retinal diseases including glaucoma and AMD, as evidenced with the deposition of $A \beta$ peptide in both diseases (see review [12]). Visual problems have been observed during the initial stages of AD [13]. Reduction in the number of ganglion cells and in the thickness of the nerve-fiber layer has been observed in $\mathrm{AD}$ patients [14]. The causes of AMD and AD are not well defined, but several factors including diet, environment, and genetic susceptibility likely contribute to the pathogenesis of these diseases [15]. Epidemiological and animal studies have suggested a link between high plasma cholesterol levels and AD [16]. As well, high intake of cholesterol and saturated fat have long been suspected to increase the risk for AMD [17]. Cholesterol (free and esterified) has been shown to be highly distributed in the human drusen [18-20]. Drusen may raise the risk of developing AMD [21]. The source of the cholesterol that accumulates in the retina is suggested to derive from both local cells and plasma origins [22-24]. Currently, the mechanisms by which cholesterol may increase the incidence of AMD are not clear. Several lines of evidence suggest that oxidized cholesterol metabolites (oxysterols) may be the link by which cholesterol contributes to the pathogenesis of AMD. The oxysterol pathway has been proposed as a unifying hypothesis for the cause of AMD [25,26]. We have shown that cholesterol-enriched diets increase $A \beta$ levels, oxidative stress and cell death in rabbit brains [27]. We have further presented ample evidence that increased levels of 27hydroxycholesterol, an oxidized cholesterol metabolite, is a potential link that mediates cholesterol-induced AD pathology $[28,29]$. We have also recently demonstrated that incubation of retinal pigment epithelial cells with the oxysterol 27-hydroxycholesterol caused $A \beta$ accumulation, oxidative stress and apoptosis [30]. Our data suggest that increased oxysterol levels, subsequently to high plasma cholesterol levels, may be a common pathogenic factor for both $\mathrm{AD}$ and AMD. However, the extent to which cholesterol-fed rabbit retinas also exhibit increased $A \beta$ levels, oxidative stress and cell death is not well known. As well, the extent to which these features are associated with increased levels of oxysterols in rabbit retinas has not been determined.

In this study, we fed rabbits with a cholesterolenriched diet for 12 weeks and found that this regimen is associated with increased levels of $A \beta$, oxidative damage, apoptotic cell death as well as increased cholesterol and oxysterol levels in retinas. Our results suggest a potential link between cholesterol metabolism and retinal degeneration.

\section{Methods}

\section{Animals and treatments}

Male New Zealand white rabbits (1.5-2 years old, 3-5 $\mathrm{kg}$ ), housed separately in cages in a room with $12 \mathrm{~h}$ dark/light cycle, were randomly assigned to 2 groups ( $\mathrm{n}=6$ each) as follows: group 1, normal chow and group 2, chow supplemented with $2 \%$ cholesterol (Harlan Teklad Global Diets, Madison, WI). Animals fed with cholesterol-enriched diet and their matched controls were euthanized 12 weeks later. At necropsy, animals were perfused with Dulbecco's phosphate-buffered saline (GIBCO) and the eyes were promptly enucleated. One eye of each animal was used for biochemical analysis and the other was immediately placed in a fixative solution for paraffin embedding. All animal procedures were carried out in accordance with the U.S. Public Health Service Policy on Humane Care and Use of Laboratory Animals and were approved by the Institutional Animal Care and Use Committee at the University of North Dakota.

\section{Immunohistochemistry}

After deparaffinization and rehydration, paraffin sections $(7 \mu \mathrm{m})$ were washed with PBS, incubated with trypsin enzymatic antigen retrieval solution (Abcam, Cambridge, MA) then blocked with $10 \%$ normal goat serum solution for $1 \mathrm{~h}$. This was followed by an overnight incubation at $4^{\circ} \mathrm{C}$ with mouse monoclonal antibody to $4 \mathrm{G} 8$ that detects A $\beta$ (1:100, Signet Laboratories, Dedham, MA), rat monoclonal to GFAP (1:50, Abcam), mouse monoclonal antibody to vitronectin (1:200, Santa Cruz Biotechnology, Santa Cruz, CA) and mouse polyclonal antibody to CYP27A1, the enzyme that converts cholesterol to 27hydroxycholesterol (1:200, Novus Biologicals, Littleton, CO). Anti-mouse IgG conjugated with Alexa Fluor 488 Dye (Molecular Probes, Eugene, OR) at 1:500 and antirat IgG conjugated with Alexa Fluor 594 Dye (Molecular Probes) at 1:500 were used as secondary antibodies and incubated in PBS for $1 \mathrm{~h}$ at room temperature. DAPI or propidium iodide was used as a counter stain for visualizing nuclei. Hematoxylin and eosin (H\&E) staining was carried out after deparaffinization and rehydration of retinal sections with xylene, ethanol and deionized $\mathrm{H}_{2} \mathrm{O}$.

\section{Quantification of $A \beta$ levels by ELISA}

$A \beta$ levels ( $A \beta 40$ and $A \beta 42)$ were quantified in the retina of control and cholesterol-fed rabbits with an ELISA kit (Invitrogen, Carlsband, CA) according to the manufacturer's protocol. Briefly, to measure the amount of $A \beta 40$ and $A \beta 42$, the wet mass of the retina was homogenized thoroughly with $8 \times$ mass of cold $5 \mathrm{M}$ guanidine $\mathrm{HCl} / 50$ $\mathrm{mM}$ Tris- $\mathrm{HCl}$. The homogenates were mixed for $3-4 \mathrm{~h}$ at room temperature and samples were diluted with cold 
reaction buffer (Dulbecco's phosphate-buffered saline with 5\% BSA and $0.03 \%$ Tween-20 supplemented with $1 \times$ protease inhibitor cocktail) and centrifuged at $16,000 \times g$ for $20 \mathrm{~min}$ at $4^{\circ} \mathrm{C}$. The supernatant was decanted, stored on ice until use, diluted 1:2 with standard diluent buffer, and quantified by colorimetric sandwich ELISA kits. The quantity of $A \beta$ in each sample was measured in duplicates. Protein concentrations of all samples were determined by standard BCA assay (Pierce Chemical $\mathrm{Co}$, Rockford, IL). A $\beta$ levels were normalized to total protein content in the samples.

\section{Western blot analysis}

Retinas dissected from control and cholesterol-fed rabbit eyes were homogenized in T-PER(tissue protein extraction reagent, Thermo Scientific, Rockford, IL) supplemented with protease and phosphatase inhibitors (Thermo Scientific). Protein concentrations were determined with BCA protein assay reagent (Pierce Chemical Co). Proteins $(10 \mu \mathrm{g})$ were separated on SDS-PAGE gels followed by transfer to a polyvinylidene difluoride membrane (Biorad, Herculus, CA) and incubated with antibodies to BACE-1 (Mouse, 1:1000, Millipore), IDE (Rabbit, 1:5000, Millipore), HO-1 (Mouse, 1:200, Assay Designs, Ann Arbor, MI), GFAP (Rat, 1:200, Abcam), Bcl-2 (Mouse, 1:100, Santa Cruz Biotechnology), Bax (Mouse, 1:100, Santa Cruz Biotechnology), gadd153 (Mouse, 1:1000, Abcam), CYP27A1 (Rabbit, 1:800, Protein Tech Group, Chicago, IL), and ABCA1 (Mouse, 1:100, Neuromics, Edina, MN). $\beta$-actin was used as a gel loading control (Mouse, 1:5000, Santa Cruz Biotechnology). For antibodies of mouse origin, goat anti-mouse secondary antibody conjugated with horseradish peroxidase (HRP, 1:5000, Biorad), for antibodies of rabbit origin goat anti-rabbit secondary antibody (1:5000, Biorad), and for antibodies of rat origin, goat anti-rat secondary (1:500, Santa Cruz Biotechnology) were used. The blots were developed with enhanced chemiluminescence (Immun-star HRP chemiluminescent kit, Bio-Rad). Bands were visualized on a PVDF membrane by using Ultra Violet Products (UVP) Bioimaging System (UVP, Upland, CA) and analyzed by LabWorks 4.5 software. Quantification of results was performed by densitometry and the results analyzed as total integrated densitometric values (arbitrary units).

\section{TUNEL Assay}

The DeadEnd Fluorometric TUNEL assay (Promega, Madison, WI) was performed for detection of apoptosis. The TUNEL staining was performed according to manufacturer's instructions. Briefly, sections were deparaffinized, rehydrated and washed with PBS. Sections were permeabilized with Triton-X, washed with PBS, incubated with terminal deoxynucleotidyl transferase, fluorescein-12dUTP. The fluorescein-12-dUTP labeled DNA was then visualized directly by fluorescence microscopy. Propidium iodide was used as counter stain for staining nucleus.

\section{Reactive Oxygen Species measurements}

Reactive Oxygen Species (ROS) generation was measured in retinal tissue homogenates using a 2'-7'-dichlorofluorescin-diacetate (DCFH-DA) as well as fluorometric detection of $\mathrm{H}_{2} \mathrm{O}_{2}$. DCFH-DA, a non-fluorescent dye, is cleaved by esterase activity to yield DCFH, which is subsequently oxidized by a variety of ROS to form dichlorofluorescein (DCF), which is fluorescent. Retinas were homogenized in T-PER using a glass homogenizer. Samples containing $25 \mu \mathrm{g}$ proteins diluted in PBS were incubated with $5 \mu \mathrm{M}$ DCFH-DA (Sigma) in the dark for 15 min. Fluorescence was measured every $15 \mathrm{~min}$ for $1 \mathrm{~h}$ with excitation and emission wavelengths of $488 \mathrm{~nm}$ and $525 \mathrm{~nm}$, respectively, using a SpectraMax Gemini EM microplate reader (Molecular Devices, Sunnyvale, CA, USA). Values are expressed as relative fluorescence units (RFU). For the measurement of hydrogen peroxide $\left(\mathrm{H}_{2} \mathrm{O}_{2}\right)$ and peroxidase activity in the retinal samples, we used Amplex Red Hydrogen Peroxide/Peroxidase Assay according to the manufacturer's instructions (Invitrogen). In the presence of peroxidase, the Amplex Red reagent reacts with $\mathrm{H}_{2} \mathrm{O}_{2}$ in a 1:1 stoichiometry and produces the red-fluorescent oxidation product, resorufin. Retinal homogenates of control and cholesterol-fed rabbits were diluted in reaction buffer and added into 96 well plates. For each well, $50 \mu \mathrm{L}$ of working solution of $100 \mu \mathrm{M}$ Amplex Red reagent and $0.2 \mathrm{U} / \mathrm{mL}$ HRP was added and fluorescence was measured after incubation. For $\mathrm{H}_{2} \mathrm{O}_{2}$ Assay, a standard curve was generated from $0 \mu \mathrm{M}$ to $5 \mu \mathrm{M}$ and $\mathrm{H}_{2} \mathrm{O}_{2}$ concentrations of retina samples were deduced from the standard curve. Similarly, for peroxidase activity determination, $100 \mu \mathrm{M}$ Amplex Red reagent containing $2 \mathrm{mM} \mathrm{H}_{2} \mathrm{O}_{2}$ was added to retinal homogenates and after incubation fluorescence was measured. Peroxidase standard curve was generated in the range from 0 to $2 \mathrm{mU} / \mathrm{ml}$. Peroxidase activity of retinal samples were deduced from standard curve. Resorufin fluorescence was measured using a SpectraMax GeminiEM (Molecular Devices) with excitation at 530-560 nm and emission at $590 \mathrm{~nm}$.

\section{Total cholesterol quantification}

Total cholesterol levels in the control and cholesterol-fed rabbit retina samples were quantified by colorimetric detection using cholesterol/cholesteryl ester quantification kit (BioVision Research Products, Mountain View, $\mathrm{CA})$ as per the manufacturer's instructions. Cholesterol was extracted from the retina samples in a solution containing a mixture of chloroform: isopropanol: NP-40 (7:11:0.1). The extract was centrifuged at $15,000 \times \mathrm{g}$ and the organic phase was transferred to a new tube. The organic phase liquid was air dried at $50^{\circ} \mathrm{C}$ to remove 
chloroform and subjected to vacuum for $30 \mathrm{~min}$ to remove trace organic solvents. The dried lipids were dissolved in $200 \mu \mathrm{L}$ of cholesterol assay buffer provided with the kit until the samples were homogeneous by either sonicating or vortexing. Standards were prepared as per the manufacturer's instructions. $1 \mu \mathrm{L}$ of the extracted sample adjusted to $50 \mu \mathrm{L} /$ well with cholesterol assay buffer was used per assay. $50 \mu \mathrm{L}$ of the reaction mix (containing $44 \mu \mathrm{L}$ of cholesterol assay buffer, $2 \mu \mathrm{L}$ of cholesterol probe, $2 \mu \mathrm{L}$ of cholesterol enzyme mix and $2 \mu \mathrm{L}$ of cholesterol esterase all provided in the kit) was added to each well containing standards and samples. After $1 \mathrm{~h}$ reaction at $37^{\circ} \mathrm{C}$ the absorbance was read at $570 \mathrm{~nm}$. The concentration of cholesterol in each sample was calculated using the standard curve and expressed as $\mathrm{mg} / \mathrm{g}$ tissue.

\section{Oxysterol levels measurement}

Oxysterols were quantified in retinas from control $(\mathrm{n}=3)$ and cholesterol-fed $(n=3)$ rabbits using a 4000 QTRAP liquid chromatography mass spectrometer (Applied Biosystems) as previously described [31].

\section{Statistical analysis}

GraphPad Prism software 4.01 was used for statistical analysis. Quantitative data are presented as mean values \pm SEM. The significance of differences between the control and cholesterol-treated group was assessed by unpaired Student's $t$ test, with $P<0.05$ considered statistically significant.

\section{Results}

\section{$A \beta$ levels were increased in retinas of cholesterol-fed} rabbits

Immunohistochemical analysis with laser scanning confocal microscopy showed increased immunoreactivity to A $\beta$ peptide in retinas from the cholesterol-fed rabbits compared to control rabbit as determined with 4G8 antibody (Figure 1A). A $\beta$ monoclonal antibody $4 \mathrm{G} 8$ is reactive to amino acid residues $17-24$ of $A \beta$ and also reacts with APP. The increase in $A \beta$ staining is detectable in the photoreceptor outer segments (OS), outer nuclear layer (ONL), inner nuclear layer (INL) and also in the ganglion cell layers (GCL). A $\beta$ quantitation by ELISA also showed an increase in both $A \beta 40$ and $A \beta 42$ forms in the retinal samples of cholesterol-fed rabbits compared to normal chow-fed rabbits (Figure 1B, C). $\mathrm{A} \beta$ levels are regulated by generation from APP upon initial cleavage by BACE-1 and degradation by IDE. Western blot analyses demonstrate that BACE-1 and IDE levels were increased in cholesterol-fed rabbit retinas (Figure 1D, E). These results suggest that both formation and degradation of $A \beta$ are enhanced by the cholesterol-enriched diet and that the increase in

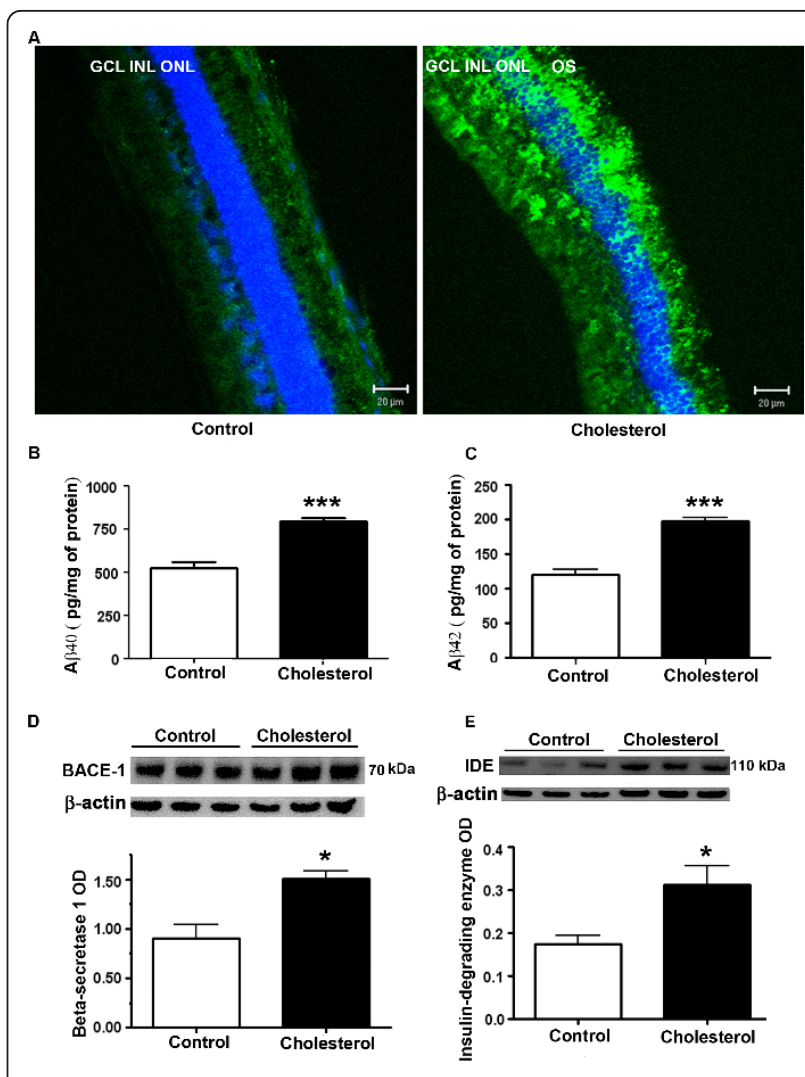

Figure $14 \mathrm{G} 8$ immunoreactivity and $A \beta$ levels were increased in cholesterol-fed rabbit retina. A. Immunohistochemical analysis of retinal sections with 4G8 (green), an antibody that detects $A \beta$, showed increased immunoreactivity in the cholesterol-fed rabbits compared to control. DAPI (blue) is a nuclear counter stain. Bar = $20 \mu \mathrm{m}$. OS, ONL, INL, GCL are outer segments, outer nuclear layer, inner nuclear layer and ganglion cell layers respectively. B, C. A $\beta$ quantification by ELISA showed an increase in levels of $A \beta 40$ and 42 in the retinal samples of cholesterol-fed rabbits compared to normal rabbits. D. BACE-1 and $\mathbf{E}$. IDE levels are increased in retinas from cholesterol-fed rabbits. ${ }^{*} p<0.05,{ }^{* *} p<0.001$ vs control.

generation by BACE-1 exceeds the degradation rate of A $\beta$ peptide by IDE.

\section{Cholesterol-fed rabbit retinas show increased oxidative stress}

The nonfluorescent dichlorofluorescein (DCFH), upon oxidation is converted to DCF and emits fluorescence. Because DCFH can be oxidized by various ROS, the increase of DCF fluorescence therefore reflects an overall oxygen species index in cells. The cholesterol-enriched diet significantly increased ROS levels in retinas compared to control animals fed normal diet as demonstrated by DCFH-DA (Figure 2A). Fluorimetric detection of $\mathrm{H}_{2} \mathrm{O}_{2}$ and peroxidase by Amplex Red Assay showed an increase in $\mathrm{H}_{2} \mathrm{O}_{2}$ levels and a decrease in peroxidase activity in retinas from cholesterol-fed rabbits compared to retinas from control rabbits (Figure 2B, C). 


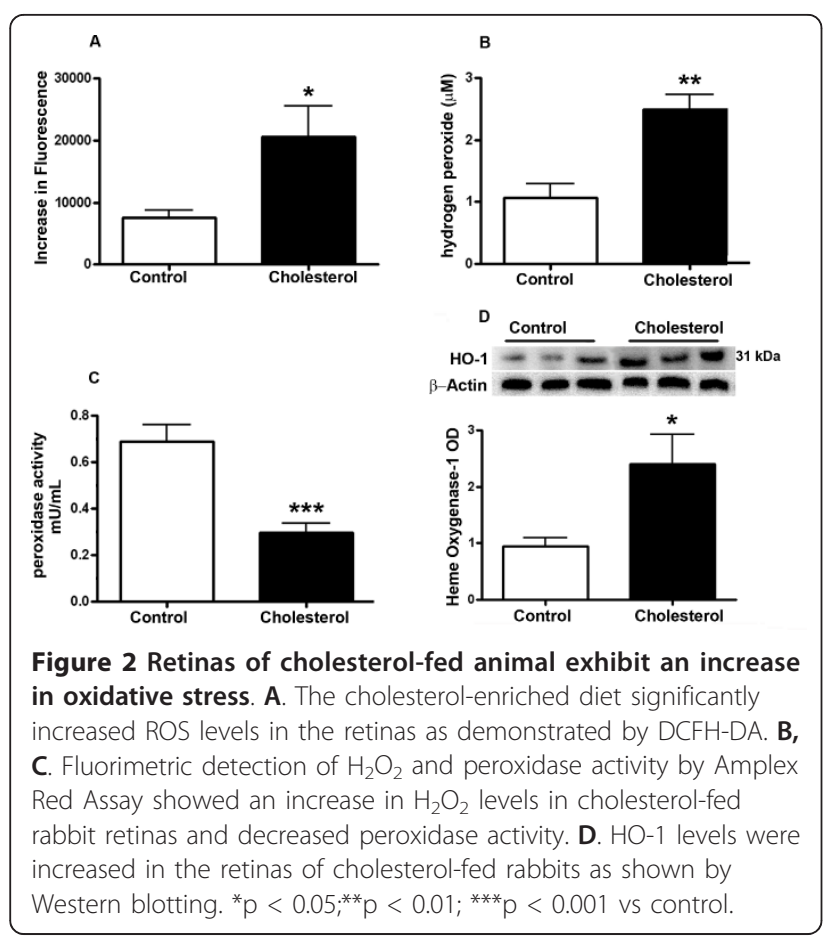

Levels of the oxidative stress sensor HO-1 were determined by Western blotting. The levels of HO-1 were significantly higher in retinas of cholesterol-fed compared to normal chow-fed rabbits (Figure 2D). All together, these results show that retinas from cholesterol-fed rabbits were subjected to oxidative stress.

\section{Cholesterol- enriched diet caused retinal morphological changes}

Astrogliosis is one of the remarkable characteristics of astrocytes to respond to oxidative stress insults. Confocal microscopy analyses show significant astrogliosis, as detected with increased immunoreactivity to GFAP in retinas from cholesterol-fed rabbits compared to control rabbits (Figure 3A). The increase in the number of astrocytes occurred in the outer nuclear, and the ganglion cell layers. Western blot analyses also show that levels of GFAP protein are dramatically increased in retinas from cholesterol-fed rabbits compared to control rabbits (Figure 3B). Vitronectin, an adhesive glycoprotein, is a common component of extracellular matrices in adult tissues including Bruch's membrane [32] and is expressed in retina. Confocal microscopy showed an increase in immunoreactivity for vitronectin antibody in the retinas of rabbits fed with cholesterol-enriched diet compared to rabbits fed with normal chow (Figure 4A). H\&E staining, analyzed by light microscopy, showed necrotic debris suggestive of drusen-like debris in retinas from cholesterol-fed rabbits. These drusen-like debris are localized under the retinal pigment epithelium (Figure 4B).

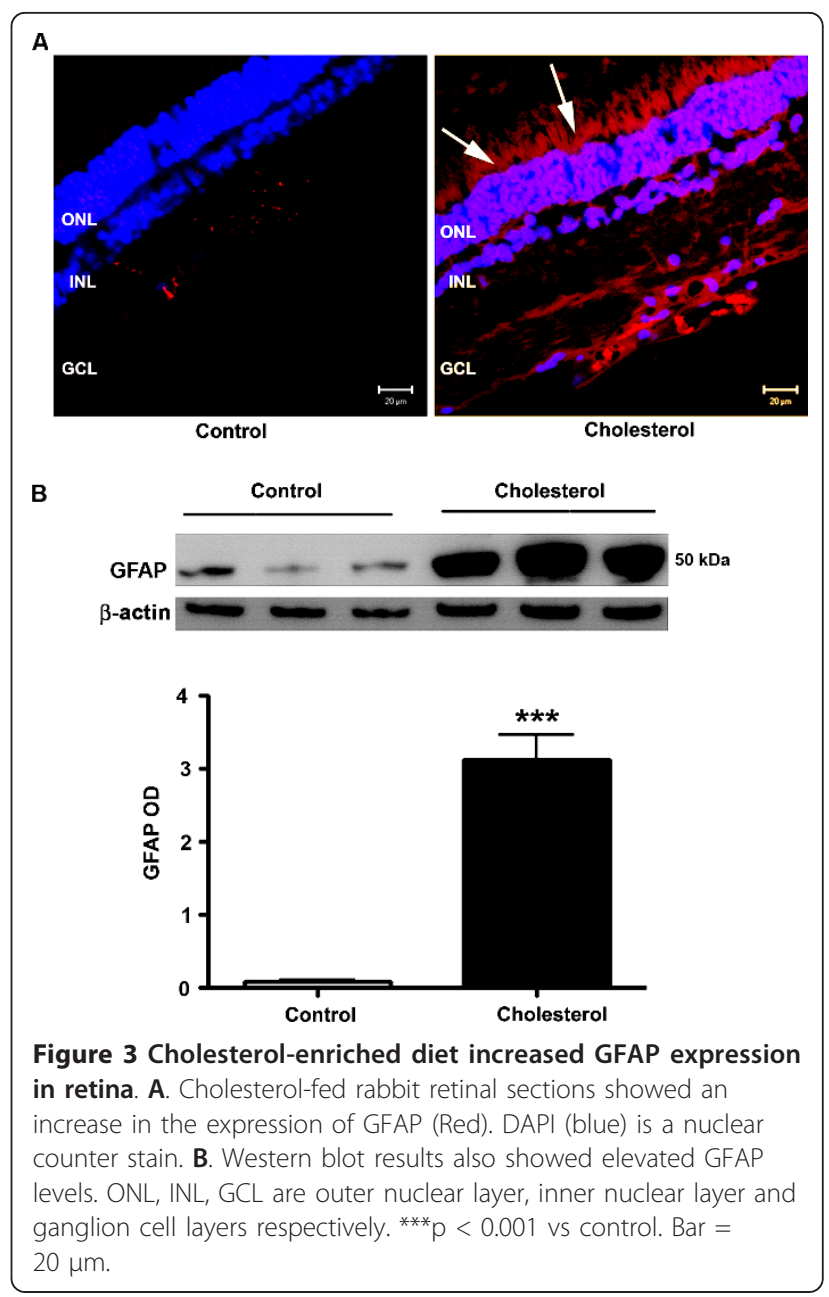

\section{Cholesterol- enriched diet caused apoptotic cell death}

Western blot results show that levels of the anti-apoptotic protein $\mathrm{Bcl}-2$ were decreased and levels of the proapoptotic protein Bax were increased in retinas of cholesterol-fed rabbits in comparison to levels of these proteins in retinas of control rabbits (Figure $5 \mathrm{~A}$ ). In addition to Bcl-2 and Bax, levels of gadd 153 were increased in cholesterol-fed rabbits (Figure 5B). Gadd 153 (also called CHOP), a transcription factor that is activated by stress to the endoplasmic reticulum, triggers cell death by mechanisms that may include generation of ROS, downregulation of $\mathrm{Bcl}-2$, and upregulation of Bax [33]. These results indicate that stress to the endoplasmic reticulum is involved in the deleterious effects of cholesterolenriched diet in retinas. TUNEL assay detects the fragmented DNA of apoptotic cells by catalytically incorporating fluorescein-12-dUTP at 3'-OH DNA ends using the Terminal Deoxynucleotidyl Transferase, and apoptotic cells fluoresce green color. TUNEL staining showed no apoptotic cells in the control retinas whereas an extensive staining was observed in the retinas of cholesterol-fed 


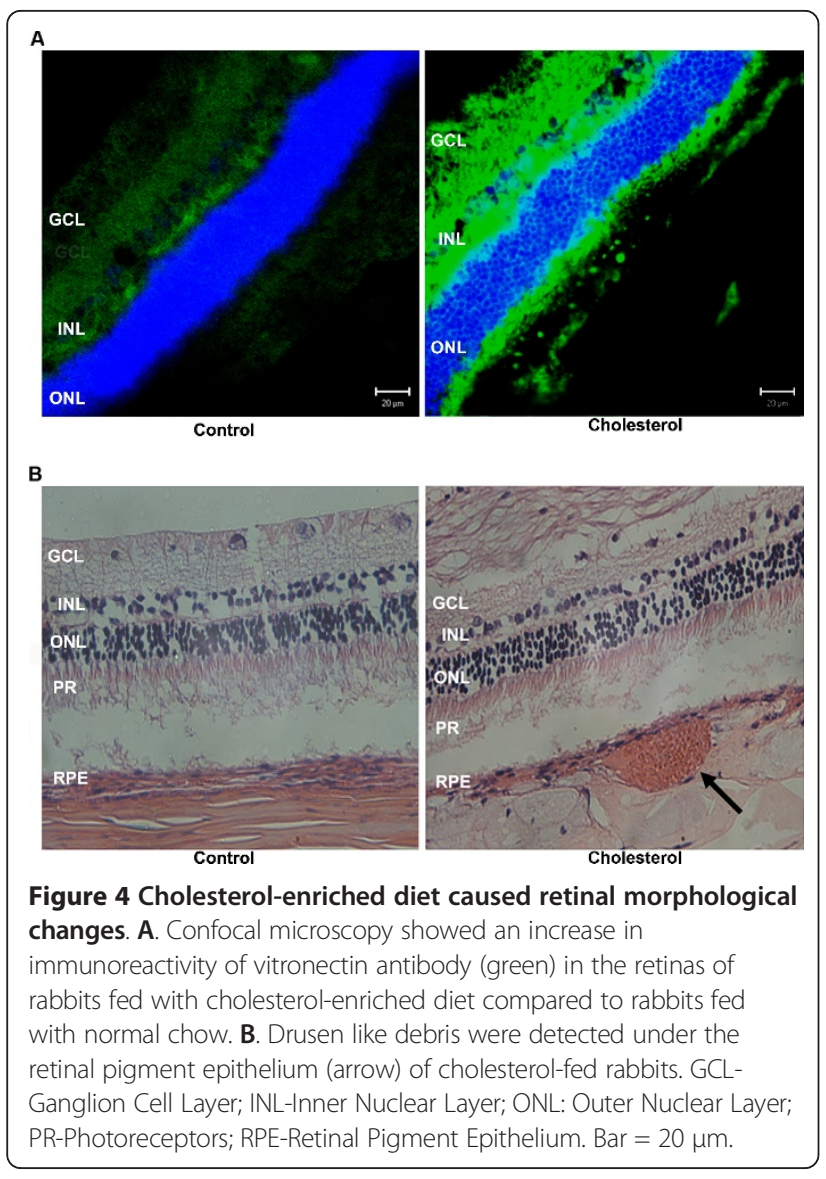

animals (Figure 5C). Propidium iodide was used as nuclear counter stain. Yellow color is the merge of green color which indicates fragmented DNA and red color that indicates nucleus.

\section{Cholesterol- enriched diet disturbed cholesterol} homeostasis in the retina

The extent to which cholesterol-enriched diet increases the accumulation of cholesterol and major oxysterols were determined in rabbit retinas (Table 1). Total cholesterol levels were increased in cholesterol fed rabbit retinas compared to control retina. The amount of cholesterol in control retinas was $0.1024 \pm 0.049 \mathrm{mg} / \mathrm{g}$ of tissue, whereas in cholesterol-fed rabbit retina the concentration of cholesterol increased to $0.8427 \pm 0.003$ $\mathrm{mg} / \mathrm{g}$ of tissue. Cholesterol is also eliminated through enzymatic conversion to polar oxysterols that include 27-hydroxycholesterol, 24-hydroxycholesterol, and 22hydroxycholesterol by CYP27A1, CYP46A1, and CYP11A1 respectively. All these enzymes were found to be expressed in the retina [34]. Mass spectrometry analysis showed a marked increase in the levels of oxysterols 27-hydroxycholesterol, 24-hydroxycholesterol, and 22-hydroxycholesterol in cholesterol-fed rabbit retinas

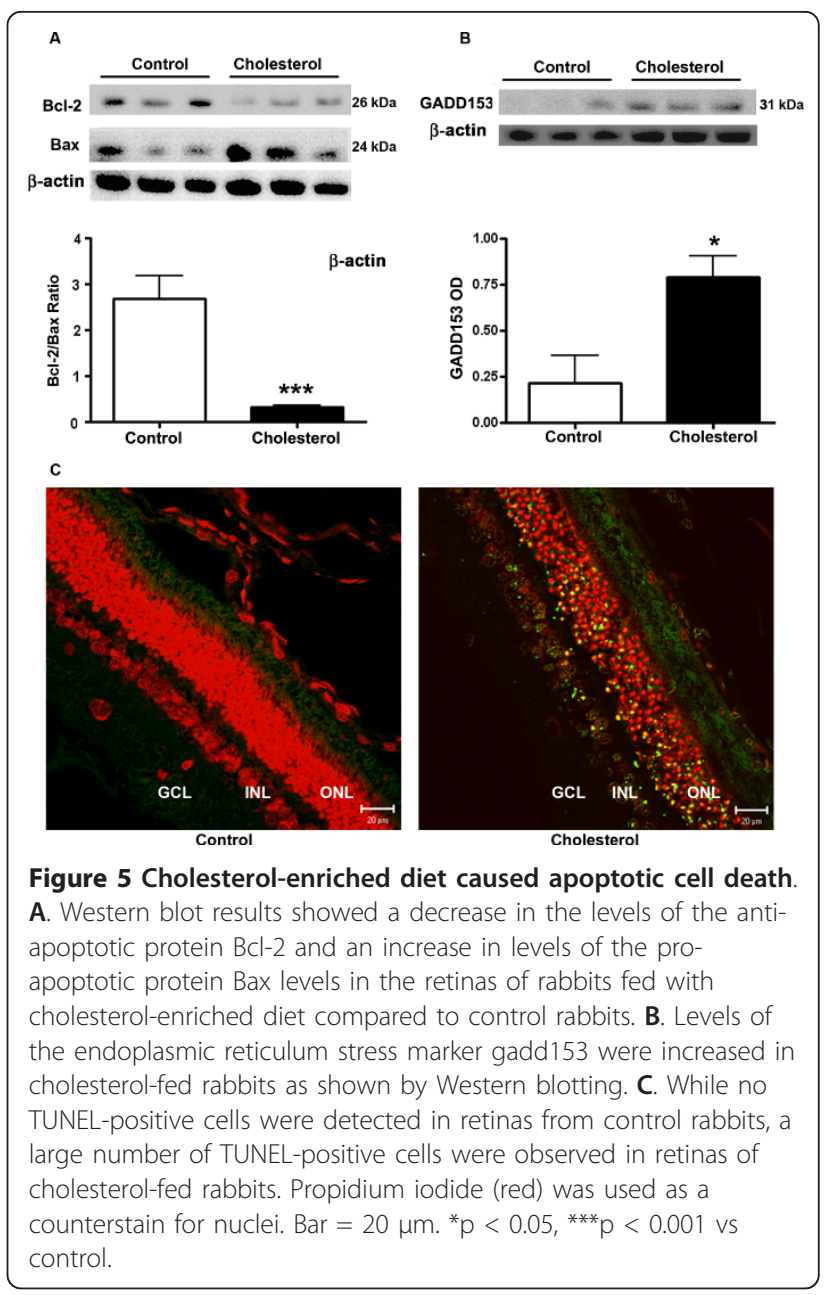

Table 1 Total cholesterol and oxysterol levels in control $(n=3)$ and cholesterol-fed rabbit retina $(n=3)$

\begin{tabular}{lcc}
\hline $\begin{array}{l}\text { Total cholesterol } \\
\text { mg/g tissue }\end{array}$ & Control retina & Cholesterol-fed retina \\
\hline $\begin{array}{l}\mathbf{4} \boldsymbol{\beta} \text {-hydroxycholesterol } \\
\text { ng/g tissue }\end{array}$ & $2491 \pm 236$ & $9046 \pm 1015^{* *}$ \\
\hline $\begin{array}{l}\mathbf{7} \boldsymbol{\alpha} \text {-hydroxycholesterol } \\
\text { ng/g tissue }\end{array}$ & $344.1 \pm 49.51$ & $14378 \pm 1504^{* *}$ \\
\hline $\begin{array}{l}\text { 22-hydroxycholesterol } \\
\text { ng/g tissue }\end{array}$ & $7.893 \pm 1.59$ & $105.6 \pm 24.71^{*}$ \\
\hline $\begin{array}{l}\text { 24-hydroxycholesterol } \\
\text { ng/g tissue }\end{array}$ & $405.3 \pm 173.9$ & $1815.32 \pm 313.5^{*}$ \\
\hline $\begin{array}{l}\mathbf{2 5 - h y d r o x y c h o l e s t e r o l ~} \\
\text { ng/g tissue }\end{array}$ & $24.39 \pm 0.20$ & $835.5 \pm 29.77^{* * *}$ \\
\hline $\begin{array}{l}\text { 27-hydroxycholesterol } \\
\text { ng/g tissue }\end{array}$ & $29.38 \pm 8.4$ & $697.2 \pm 161.4^{*}$ \\
\hline
\end{tabular}

Values are expressed as mean \pm SEM. ${ }^{*} p<0.05$; ${ }^{* *} p<0.01$; ${ }^{* * *} p<0.001$ vs control. 
(Table 1). We also measured the other enzymaticallygenerated oxysterols, $7 \alpha$-hydroxycholesterol, $4 \beta$-hydroxycholesterol and 25-hydroxycholesterol, and found an increase in their levels in retinas from cholesterol-fed rabbits.

As we have previously shown that 27-hydroxycholesterol is toxic to RPE cells [30], we determined levels of CYP27A1, the enzyme that converts cholesterol to 27hydroxycholesterol. CYP27A1 immunoreactivity was dramatically increased in retinas from cholesterol-fed rabbits compared to control rabbits (Figure 6A). Western blotting also showed a significant increase in CYP27A1 levels in retinas from cholesterol-fed rabbits compared to those in retinas of control rabbits (Figure 6B). The cholesterol transporter ATP-binding cassette sub-family A member 1 (ABCA-1) shuttles cholesterol between various cells. Levels of ABCA-1 were dramatically increased in retinas of cholesterol-fed rabbits in comparison to levels in retinas of control rabbits (Figure 6C). All together, these results demonstrate accumulation of cholesterol and increased conversion to oxysterols in retinas as a result of cholesterol-enriched diet.

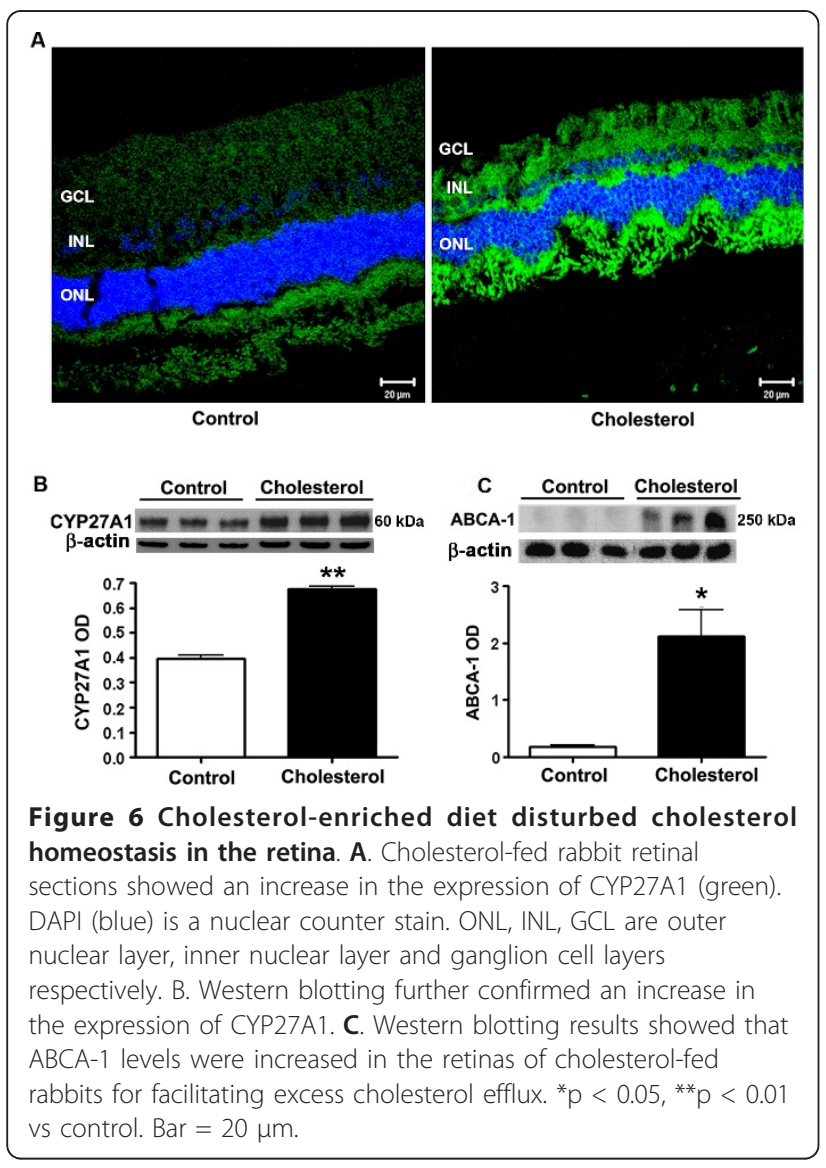

\section{Discussion}

Strong evidence linking AD and retinal degeneration [12] is the reason behind this study. Retina is an extension of the brain, and has the potential to reflect AD brain pathology. Extracellular A $\beta$ deposition, oxidative stress, and inflammation are implicated in both AD and AMD $[4,5]$. Ganglion cell death has been recently documented in retinas of AD mouse models [35]. AMD is characterized by the abnormal, extracellular deposits of cellular debris called drusen that are located between Bruch's membrane (BM) and the RPE. Drusen contain various components including amyloid- $\beta$ peptides $[7,36]$. Amyloid misfolding-inducing inflammation has been suggested to mediate retinal neurodegeneration [37]. Cholesterol dyshomeostasis has been implicated in the pathogenesis of AD [38] and high-fat diet rich in saturated fatty acids and cholesterol is suggested to be associated with AMD [17]. We determined here the extent to which the cholesterol-fed rabbit model for AD also exhibits retinal pathology relevant to AMD. We demonstrate that cholesterol-enriched diet increased $A \beta$ levels and oxidative stress, induces apoptotic cell death and morphological changes, and alters cholesterol metabolism in rabbit retinas.

$\mathrm{A} \beta$ steady state levels are determined by the balance between its production and clearance. $A \beta$ is generated from APP and degraded by several enzymes. Initial cleavage of APP involves BACE- 1 enzyme to yield $A \beta$ (A $\beta 40$ and $A \beta 42$ ). $A \beta 40$ and $A \beta 42$ are then degraded by various enzymes including IDE. We demonstrate here that feeding rabbits a diet rich in cholesterol increased $\mathrm{A} \beta$ peptide levels as well as levels of BACE-1. These results suggest that increased $A \beta$ levels in rabbit retinas are derived from an increased production from APP by BACE-1. It may also be possible that increased $A \beta$ transport from the circulation to retinas contributes to the elevated levels of $\mathrm{A} \beta$ peptide in retinas. In $\mathrm{AD}$ brains, while some studies showed an increase in IDE [39-42], others have showed reduction of IDE in AD $[43,44]$. In one of the studies, it was suggested that the reduction in IDE activity is not the primary cause of $A \beta$ accumulation but rather is a late stage phenomenon secondary to neurodegeneration [39]. We found here that retinal IDE levels were increased in the cholesterol-fed animals. The increase in IDE levels may have been a mechanism for coping up with the $A \beta$ overload.

As $A \beta$ is a neurotoxic peptide and its accumulation in the retina may promote oxidative damage and cell death, we determined the extent to which accumulation of $A \beta$ peptide is associated with increased ROS and apoptotic cell death. We demonstrate that cholesterolenriched diet-induced $A \beta$ accumulation is associated with increased oxidative stress. Proteins, carbohydrates, 
membrane lipids and nucleic acids are all vulnerable to reactive oxygen species damage, and this damage is believed to contribute to the pathogenesis of many diseases. Oxidative injury to cells is associated with several diseases, including AD [45] and AMD [46]. DCFH-DA assay indicated that there is an increase in ROS in the retinas of cholesterol-fed rabbits. Hydrogen peroxide, which is also considered as reactive oxygen species, was increased and peroxidase activity is decreased in cholesterol-fed rabbit retinas. HO-1 is a sensor of oxidative stress that degrades heme, leading to formation of biliverdin and carbon monoxide $[47,48]$. HO-1 has been shown to be increased in RPE of AMD-affected macula [49]. HO-1 induction is suggested to be an early event in the pathogenesis of sporadic AD [50] and has been demonstrated to be closely associated with neurofibrillary pathology in AD [51]. Neurons of the AD temporal cortex and hippocampus has significantly more HO-1 immunoreactivity than corresponding tissues derived from non-demented controls [52]. We have previously shown that cholesterol-fed rabbits exhibit increased levels of ROS and $\mathrm{HO}-1$ in addition to increased $\mathrm{A} \beta$ in the brain [53]. Here we show that HO-1 levels are increased in the retinas of cholesterol-fed rabbits.

Pathogenesis of many retinal and ocular diseases involves apoptosis. Histopathological studies suggest that the retinal pigment epithelium damage occurs first, followed by death of photoreceptors [54], with rod photoreceptor cell loss preceding that of cone photoreceptor cells $[55,56]$. Photoreceptors underwent apoptosis in 4 of 16 eyes with AMD [57]. It was shown that apoptosis is the cause of photoreceptor cell death in three mouse models of Retinitis pigmentosa [58]. It was also shown that photic exposure triggers apoptosis of photoreceptor cells [59]. Retinal ganglion cells also undergo apoptosis in glaucoma [60,61]. As apoptosis may be involved in AMD and other retinal diseases and cholesterol-enriched diet has been shown to induce apoptosis in rabbit brains [53], we determined the extent to which cholesterol induces apoptotic cell death in retinas. The B-cell lymphoma-2 family of proteins includes both pro- and anti-apoptotic members. Bcl-2 is the most prominent anti-apoptotic member and is an important regulator of photoreceptor cell death in retinal degenerations [62]. Bcl-2 has been shown to decrease apoptosis by facilitating recovery of mitochondrial DNA damage [63]. Our results show that levels of the anti-apoptotic protein Bcl-2 were decreased and levels of the pro-apoptotic protein Bax were increased in retinas of cholesterol-fed rabbits. We also show that cholesterol-enriched diet increased levels of gadd153, a protein that induces cell death and upsets the cellular redox state by depleting cellular glutathione and exaggerating the production of ROS [64].
Development of drusen is one of the earliest clinical features of AMD. Drusen are extracellular deposits of lipids, proteins, glycoproteins, and cellular debris that accumulate between collagenous layer of Bruch's membrane and basal lamina of the retinal pigment epithelium. Recent studies found many drusen constituents including cholesterol, apolipoproteins, and complement components $[24,65]$. In our study, we detected debris-like material between RPE and choroid capillaries in retinas of cholesterol-fed rabbits. The debris-like material known as drusen is regarded as a hallmark of AMD. In addition, GFAP is strongly upregulated in glial cells in response to neuronal damage and is best known marker for gliosis. Retinal macroglial cells (astrocytes and Müller cells) have been shown to have an active role in normal retinal function [66] as well as in pathology [67]. Upregulation of GFAP expression, an indicator of reactive gliosis, has been demonstrated in response to various retinal pathologies including mechanical injury [68], retinal detachment [69], diabetic retinopathy [70], glaucoma [71], retinal ischemia [72] and photoreceptor degeneration [73]. Increased GFAP expression in macroglia has also been described in retinas with AMD [74-76]. We also found that retinas of cholesterol-fed rabbits exhibit astrogliosis as determined with GFAP immunostaining. Vitronectin has regulatory roles in inflammation and phagocytosis [77]. Increased vitronectin deposition in retina is suggested to participate in the pathogenesis of AMD [32]. Our results also show a marked increase in vitronectin immunoreactivity in retinas from cholesterolfed rabbits.

All together, our data demonstrate that cholesterolenriched diets cause structural and morphological changes relevant to AMD. However, the mechanisms by which dietary cholesterol cause these changes in retinas are not well known. Recent genome wide association studies implicated cholesterol metabolism involvement in AMD $[78,79]$. Cholesterol is constantly taken up by retina via LDL receptors from the circulation in addition to endogenous cholesterol synthesis. Here we found out that cholesterol-enriched diet caused an accumulation of cholesterol in the retina. As excess cholesterol in cells is detrimental, various mechanisms are necessary for cholesterol efflux from cells. These mechanisms include passive diffusion, conversion to oxysterols, and reverse cholesterol transport. ABCA-1 has been shown to play a role in the transport of cholesterol, and was detected in the retina of various organisms [80,81]. ABCA-1 levels are increased in the cholesterol-fed rabbits, implying an increase in the cholesterol content in cells and efflux through ABCA-1. Cholesterol can be oxidized by enzymatic and non-enzymatic pathways. One of the most important enzymatically generated side-chain oxysterol is 
27-hydroxycholesterol. This oxysterol is formed from cholesterol by cytochrome P450's CYP27A1 [82]. We found that CYP27A1 expression was increased in retinas of cholesterol-fed rabbits as shown by laser scanning confocal microscopy and Western blotting. We further show an increase in 27-hydroxycholesterol and other oxysterols concentrations in retinas by mass spectrometry. We found that 27-hydroxycholesterol, 22- hydroxycholesterol and 24- hydroxycholesterol levels were increased in cholesterol-fed rabbit retinas providing evidence that elimination of excess cholesterol to oxysterols takes place in the retina. In contrast to our results in rabbit, a recent study could not detect $27-\mathrm{OHC}$ in the bovine and human retinas, but found that its oxidation product, 5-cholestenoic acid is the most abundant oxysterol [83]. We did not measure 5-cholestenoic acid in our study. We also measured other enzymatically generated oxysterols including $7 \alpha$-hydroxycholesterol, $4 \beta$-hydroxycholesterol and 25-hydroxycholesterol catalyzed by CYP7A1, CYP3A4 and cholesterol 25-hydroxylase respectively. These enzymes oxidize cholesterol for various purposes including cholesterol elimination. Even though none of these enzymes were reported to be expressed in the retina, their oxysterol products were found in retinas, most probably coming from blood circulation as retina has access to blood borne lipids [84]. These finding suggest an increase in cholesterol in retinas as well as an increase in cholesterol oxidizing enzyme metabolites. Numerous studies suggested cytotoxic effects of oxysterols are associated with human diseases including AD and AMD (see for review [85]). Increased oxysterol concentrations subsequently to increased cholesterol levels may contribute to the generation of AMD-like pathological hallmarks.

\section{Conclusions}

AMD and AD share many pathological features including accumulation of $A \beta$, increased oxidative stress, and apoptotic cell death. The causes of AMD and AD are not well known but dietary and environmental factors may contribute to the pathogenesis of these diseases. We demonstrate here that cholesterol-enriched diet induces changes that are relevant to AMD. We further suggest that increased conversion of cholesterol to oxysterols might be a potential mechanism linking high cholesterol to AMD pathology.

\footnotetext{
Acknowledgements

Supported by a grant from NIEHS/NIH to OG (R01ES014826). The authors thank Dr. David Russell (University of Texas South Western Medical Center) for measurements of oxysterols with mass spectrometry. The authors also thank Dr. Byron Grove and Sarah Rolling (Department of Anatomy and Cell Biology, School of Medicine \& Health Sciences, University of North Dakota) for their technical assistance in confocal microscopy.
}

\section{Author details}

${ }^{1}$ Department of Pharmacology, Physiology and Therapeutics, University of North Dakota School of Medicine and Health Sciences, Grand Forks, North Dakota, 58202, USA. ²Department of Biochemistry and Molecular Biology, University of North Dakota School of Medicine and Health Sciences, Grand Forks, North Dakota, 58202, USA.

\section{Authors' contributions}

BD performed most experiments and analyzed the data. ELISA experiments were done by JPRP. GM participated in Western blot experiments and provided input in the experimental design. OG and BS conceived the study and supervised the results and wrote the final draft. All authors read and approved the final manuscript.

\section{Competing interests}

The authors declare that they have no competing interests.

Received: 6 March 2011 Accepted: 18 August 2011

Published: 18 August 2011

\section{References}

1. Sarks SH: Council Lecture. Drusen and their relationship to senile macular degeneration. Aust J Ophthalmol 1980, 8:117-130.

2. Green WR, Enger C: Age-related macular degeneration histopathologic studies. The 1992 Lorenz E. Zimmerman Lecture. Ophthalmology 1993, 100:1519-1535.

3. Curcio CA, Presley JB, Millican CL, Medeiros NE: Basal deposits and drusen in eyes with age-related maculopathy: evidence for solid lipid particles. Exp Eye Res 2005, 80:761-775.

4. Ding $X$, Patel M, Chan CC: Molecular pathology of age-related macular degeneration. Progress in Retinal and Eye Research 2009, 28:1-18.

5. Butterfield DA, Griffin S, Munch G, Pasinetti GM: Amyloid beta-peptide and amyloid pathology are central to the oxidative stress and inflammatory cascades under which Alzheimer's disease brain exists. J Alzheimers Dis 2002, 4:193-201.

6. Kaarniranta K, Salminen A, Haapasalo A, Soininen H, Hiltunen M: AgeRelated Macular Degeneration (AMD): Alzheimer's Disease in the Eye? J Alzheimers Dis 2011.

7. Dentchev T, Milam AH, Lee VM, Trojanowski JQ, Dunaief JL: Amyloid-beta is found in drusen from some age-related macular degeneration retinas, but not in drusen from normal retinas. Mol Vis 2003, 9:184-190.

8. Johnson LV, Leitner WP, Rivest AJ, Staples MK, Radeke MJ, Anderson DH: The Alzheimer's $A \beta$-peptide is deposited at sites of complement activation in pathologic deposits associated with aging and age-related macular degeneration. Proceedings of the National Academy of Sciences of the United States of America 2002, 99:11830-11835.

9. Luibl V, Isas JM, Kayed R, Glabe CG, Langen R, Chen J: Drusen deposits associated with aging and age-related macular degeneration contain nonfibrillar amyloid oligomers. J Clin Invest 2006, 116:378-385.

10. Malek G, Johnson LV, Mace BE, Saloupis P, Schmechel DE, Rickman DW, Toth CA, Sullivan PM, Rickman CB: Apolipoprotein E allele-dependent pathogenesis: a model for age-related retinal degeneration. Proc Nat/ Acad Sci USA 2005, 102:11900-11905.

11. Ding JD, Lin J, Mace BE, Herrmann R, Sullivan P, Bowes RC: Targeting agerelated macular degeneration with Alzheimer's disease based immunotherapies: anti-amyloid-beta antibody attenuates pathologies in an age-related macular degeneration mouse model. Vision Res 2008, 48:339-345.

12. Guo L, Duggan J, Cordeiro MF: Alzheimer's disease and retinal neurodegeneration. Curr Alzheimer Res 2010, 7:3-14.

13. Sadun AA, Borchert M, DeVita E, Hinton DR, Bassi CJ: Assessment of visual impairment in patients with Alzheimer's disease. Am J Ophthalmol 1987, 104:113-120.

14. Hinton DR, Sadun AA, Blanks JC, Miller CA: Optic-nerve degeneration in Alzheimer's disease. N Engl J Med 1986, 315:485-487.

15. Ohno-Matsui $\mathrm{K}$ : Parallel findings in age-related macular degeneration and Alzheimer's disease. Progress in Retinal and Eye Research 2011, 30:217-238.

16. Solomon A, Kivipelto M, Wolozin B, Zhou J, Whitmer RA: Midlife Serum Cholesterol and Increased Risk of Alzheimer's and Vascular Dementia Three Decades Later. Dementia and Geriatric Cognitive Disorders 2009, 28:75-80. 
17. Mares-Perlman JA, Brady WE, Klein R, VandenLangenberg GM, Klein BE, Palta M: Dietary fat and age-related maculopathy. Arch Ophthalmol 1995 113:743-748.

18. Rudolf M, Curcio CA: Esterified cholesterol is highly localized to Bruch's membrane, as revealed by lipid histochemistry in wholemounts of human choroid. J Histochem Cytochem 2009, 57:731-739.

19. Curcio CA, Presley JB, Malek G, Medeiros NE, Avery DV, Kruth HS: Esterified and unesterified cholesterol in drusen and basal deposits of eyes with age-related maculopathy. Exp Eye Res 2005, 81:731-741.

20. Li CM, Clark ME, Rudolf M, Curcio CA: Distribution and composition of esterified and unesterified cholesterol in extra-macular drusen. Exp Eye Res 2007, 85:192-201

21. Green WR: Histopathology of age-related macular degeneration. Mol Vis 1999, 5:27.

22. Holz FG, Sheraidah G, Pauleikhoff D, Bird AC: Analysis of lipid deposits extracted from human macular and peripheral Bruch's membrane. Arch Ophthalmol 1994, 112:402-406.

23. Trivino A, Ramirez Al, Salazar JJ, de HR, Rojas B, Padilla E, Tejerina T, Ramirez JM: A cholesterol-enriched diet induces ultrastructural changes in retinal and macroglial rabbit cells. Exp Eye Res 2006, 83:357-366.

24. Malek G, Li CM, Guidry C, Medeiros NE, Curcio CA: Apolipoprotein B in cholesterol-containing drusen and basal deposits of human eyes with age-related maculopathy. Am J Pathol 2003, 162:413-425.

25. Javitt NB, Javitt JC: The retinal oxysterol pathway: a unifying hypothesis for the cause of age-related macular degeneration. Curr Opin Ophthalmol 2009, 20:151-157.

26. Javitt NB: Oxysterols: functional significance in fetal development and the maintenance of normal retinal function. Curr Opin Lipidol 2007, 18:283-288.

27. Ghribi O, Larsen B, Schrag M, Herman MM: High cholesterol content in neurons increases BACE, beta-amyloid, and phosphorylated tau levels in rabbit hippocampus. Exp Neurol 2006, 200:460-467.

28. Prasanthi JR, Huls A, Thomasson S, Thompson A, Schommer E, Ghribi O: Differential effects of 24-hydroxycholesterol and 27-hydroxycholesterol on beta-amyloid precursor protein levels and processing in human neuroblastoma SH-SY5Y cells. Mol Neurodegener 2009, 4:1.

29. Ghribi O, Schommer E, Prasanthi JRP: 27-hydroxycholestrol as the missing link between circulating cholesterol and AD-like pathology. Alzheimer's and Dementia 2009, 5:180.

30. Dasari B, Prasanthi J, Marwarha G, Singh B, Ghribi O: The oxysterol 27hydroxycholesterol increases beta-amyloid and oxidative stress in retinal pigment epithelial cells. BMC Ophthalmology 2010, 10:22.

31. McDonald JG, Thompson BM, McCrum EC, Russell DW: Extraction and Analysis of Sterols in Biological Matrices by High Performance Liquid Chromatography Electrospray Ionization Mass Spectrometry. 2007, 432:145-170.

32. Hageman GS, Mullins RF, Russell SR, Johnson LV, Anderson DH: Vitronectin is a constituent of ocular drusen and the vitronectin gene is expressed in human retinal pigmented epithelial cells. FASEB J 1999, 13:477-484.

33. Oyadomari S, Mori M: Roles of CHOP/GADD153 in endoplasmic reticulum stress. Cell Death Differ 2004, 11:381-389.

34. Rodriguez IR, Larrayoz IM: Cholesterol oxidation in the retina: implications of $7 \mathrm{KCh}$ formation in chronic inflammation and age-related macular degeneration. J Lipid Res 2010, 51:2847-2862.

35. Cordeiro MF, Guo L, Coxon KM, Duggan J, Nizari S, Normando EM, Sensi SL, Sillito AM, Fitzke FW, Salt TE, Moss SE: Imaging multiple phases of neurodegeneration: a novel approach to assessing cell death in vivo. Cell Death and Dis 2010, 1:e3.

36. Bressler SB, Maguire MG, Bressler NM, Fine SL, the Macular Photocoagulation Study Group: Relationship of Drusen and Abnormalities of the Retinal Pigment Epithelium to the Prognosis of Neovascular Macular Degeneration. Arch Ophthalmol 1990, 108:1442-1447.

37. Berisha F, Feke GT, Trempe CL, McMeel JW, Schepens CL: Retinal Abnormalities in Early Alzheimer's Disease. Invest Ophthalmol Vis Sci 2007 48:2285-2289

38. Wellington CL: Cholesterol at the crossroads: Alzheimer's disease and lipid metabolism. Clin Genet 2004, 66:1-16.

39. Caccamo A, Oddo S, Sugarman MC, Akbari Y, LaFerla FM: Age- and regiondependent alterations in $A \beta$-degrading enzymes: implications for $A \beta$ induced disorders. Neurobiology of Aging 2005, 26:645-654
40. Dorfman VB, Pasquini L, Riudavets M, Lopez-Costa JJ, Villegas A, Troncoso JC, Lopera F, Castano EM, Morelli L: Differential cerebral deposition of IDE and NEP in sporadic and familial Alzheimer's disease. Neurobiology of Aging 2010, 31:1743-1757.

41. Vepsalainen S, Hiltunen M, Helisalmi S, Wang J, van Groen T, Tanila H, Soininen $H$ : Increased expression of $A \beta$ degrading enzyme IDE in the cortex of transgenic mice with Alzheimer's disease-like neuropathology. Neuroscience Letters 2008, 438:216-220.

42. Miners JS, Baig S, Tayler H, Kehoe PG, Love S: Neprilysin and insulindegrading enzyme levels are increased in Alzheimer disease in relation to disease severity. J Neuropathol Exp Neurol 2009, 68:902-914.

43. Perez A, Morelli L, Cresto JC, Castano EM: Degradation of Soluble Amyloid B-Peptides 1-40, 1-42, and the Dutch Variant 1-40Q by Insulin Degrading Enzyme from Alzheimer Disease and Control Brains. Neurochemical Research 2000, 25:247-255.

44. Cook DG, Leverenz JB, McMillan PJ, Kulstad JJ, Ericksen S, Roth RA, Schellenberg GD, Jin LW, Kovacina KS, Craft S: Reduced Hippocampal Insulin-Degrading Enzyme in Late-Onset Alzheimer's Disease Is Associated with the Apolipoprotein E-ع4 Allele. Am J Pathol 2003, 162:313-319.

45. Aksenov MY, Aksenova MV, Butterfield DA, Geddes JW, Markesbery WR: Protein oxidation in the brain in Alzheimer's disease. Neuroscience 2001, 103:373-383.

46. A randomized, placebo-controlled, clinical trial of high-dose supplementation with vitamins $C$ and $E$ and beta carotene for agerelated cataract and vision loss: AREDS report no. 9. Arch Ophthalmol 2001, 119:1439-1452.

47. Tenhunen R, Marver HS, Schmid R: The enzymatic conversion of heme to bilirubin by microsomal heme oxygenase. Proceedings of the National Academy of Sciences of the United States of America 1968, 61:748-755.

48. Maines MD: Heme oxygenase: function, multiplicity, regulatory mechanisms, and clinical applications. FASEB J 1988, 2:2557-2568.

49. Frank RN: "Oxidative protector" enzymes in the macular retinal pigment epithelium of aging eyes and eyes with age-related macular degeneration. Trans Am Ophthalmol Soc 1998, 96:635-689.

50. Schipper HM, Bennett DA, Liberman A, Bienias JL, Schneider JA, Kelly J, Arvanitakis Z: Glial heme oxygenase-1 expression in Alzheimer disease and mild cognitive impairment. Neurobiol Aging 2006, 27:252-261.

51. Smith MA, Kutty RK, Richey PL, Yan SD, Stern D, Chader GJ, Wiggert B, Petersen RB, Perry G: Heme oxygenase-1 is associated with the neurofibrillary pathology of Alzheimer's disease. Am J Pathol 1994, 145:42-47.

52. Schipper HM, Cisse S, Stopa EG: Expression of heme oxygenase-1 in the senescent and Alzheimer-diseased brain. Ann Neurol 1995, 37:758-768.

53. Ghribi O, Golovko MY, Larsen B, Schrag M, Murphy EJ: Deposition of iron and beta-amyloid plaques is associated with cortical cellular damage in rabbits fed with long-term cholesterol-enriched diets. J Neurochem 2006, 99:438-449.

54. Sarks JP, Sarks SH, Killingsworth MC: Evolution of geographic atrophy of the retinal pigment epithelium. Eye (Lond) 1988, 2(Pt 5):552-577.

55. Curcio CA: Photoreceptor topography in ageing and age-related maculopathy. Eye (Lond) 2001, 15:376-383.

56. Curcio CA, Medeiros NE, Millican CL: Photoreceptor loss in age-related macular degeneration. Invest Ophthalmol Vis Sci 1996, 37:1236-1249.

57. Xu GZ, Li WW, Tso MO: Apoptosis in human retinal degenerations. Trans Am Ophthalmol Soc 1996, 94:411-430.

58. Portera-Cailliau C, Sung CH, Nathans J, Adler R: Apoptotic photoreceptor cell death in mouse models of retinitis pigmentosa. Proceedings of the National Academy of Sciences of the United States of America 1994, 91:974-978.

59. Abler AS, Chang CJ, Ful J, Tso MO, Lam TT: Photic injury triggers apoptosis of photoreceptor cells. Res Commun Mol Pathol Pharmacol 1996, 92:177-189.

60. Quigley HA, Nickells RW, Kerrigan LA, Pease ME, Thibault DJ, Zack DJ: Retinal ganglion cell death in experimental glaucoma and after axotomy occurs by apoptosis. Invest Ophthalmol Vis Sci 1995, 36:774-786.

61. Kerrigan LA, Zack DJ, Quigley HA, Smith SD, Pease ME: TUNEL-Positive Ganglion Cells in Human Primary Open-angle Glaucoma. Arch Ophthalmol 1997, 115:1031-1035.

62. Chen J, Flannery JG, LaVail MM, Steinberg RH, Xu J, Simon Ml: bcl-2 overexpression reduces apoptotic photoreceptor cell death in three 
different retinal degenerations. Proceedings of the National Academy of Sciences of the United States of America 1996, 93:7042-7047.

63. Deng G, Su JH, Ivins KJ, Van Houten B, Cotman CW: Bcl-2 Facilitates Recovery from DNA Damage after Oxidative Stress. Experimental Neurology 1999, 159:309-318.

64. McCullough KD, Martindale JL, Klotz LO, Aw TY, Holbrook NJ: Gadd153 Sensitizes Cells to Endoplasmic Reticulum Stress by Down-Regulating $\mathrm{Bcl} 2$ and Perturbing the Cellular Redox State. Mol Cell Biol 2001, 21:1249-1259

65. Crabb JW, Miyagi M, Gu X, Shadrach K, West KA, Sakaguchi H, Kamei M, Hasan A, Yan L, Raybor ME, Salomon RG, Hollyfield JG: Drusen proteome analysis: an approach to the etiology of age-related macular degeneration. Proc Natl Acad Sci USA 2002, 99:14682-14687.

66. Newman E, Reichenbach A: The Muller cell: a functional element of the retina. Trends Neurosci 1996, 19:307-312.

67. Dyer MA, Cepko CL: Control of Muller glial cell proliferation and activation following retinal injury. Nat Neurosci 2000, 3:873-880.

68. Bignami A, Dahl D: The radial glia of Muller in the rat retina and their response to injury. An immunofluorescence study with antibodies to the glial fibrillary acidic (GFA) protein. Exp Eye Res 1979, 28:63-69.

69. Okada M, Matsumura M, Ogino N, Honda Y: Muller cells in detached human retina express glial fibrillary acidic protein and vimentin. Graefes Arch Clin Exp Ophthalmol 1990, 228:467-474.

70. Mizutani M, Gerhardinger C, Lorenzi M: Muller cell changes in human diabetic retinopathy. Diabetes 1998, 47:445-449.

71. Wang X, Tay SS, Ng YK: An immunohistochemical study of neuronal and glial cell reactions in retinae of rats with experimental glaucoma. Exp Brain Res 2000, 132:476-484.

72. Nishiyama T, Nishukawa S, Hiroshi, Tomita, Tamai M: Muller cells in the preconditioned retinal ischemic injury rat. Tohoku J Exp Med 2000, 191:221-232.

73. Eisenfeld AJ, Bunt-Milam AH, Sarthy PV: Muller cell expression of glial fibrillary acidic protein after genetic and experimental photoreceptor degeneration in the rat retina. Invest Ophthalmol Vis Sci 1984, 25:1321-1328.

74. Madigan MC, Penfold PL, Provis JM, Balind TK, Billson FA: Intermediate filament expression in human retinal macroglia. Histopathologic changes associated with age-related macular degeneration. Retina 1994, 14:65-74.

75. Ramirez JM, Ramirez Al, Salazar JJ, de HR, Trivino A: Changes of astrocytes in retinal ageing and age-related macular degeneration. Exp Eye Res 2001, 73:601-615.

76. Guidry C, Medeiros NE, Curcio CA: Phenotypic variation of retinal pigment epithelium in age-related macular degeneration. Invest Ophthalmol Vis Sci 2002, 43:267-273.

77. Preissner KT, Seiffert D: Role of vitronectin and its receptors in haemostasis and vascular remodeling. Thromb Res 1998, 89:1-21.

78. Chen W, Stambolian D, Edwards AO, Branham KE, Othman M, Jakobsdottir J, et al: Genetic variants near TIMP3 and high-density lipoprotein-associated loci influence susceptibility to age-related macular degeneration. Proceedings of the National Academy of Sciences 2010, 107:7401-7406.

79. Neale BM, Fagerness J, Reynolds R, Sobrin L, Parker M, Raychaudhuri S, Tan PL, Oh EC, Merriam JE, Souied E, Bernstein PS, Li B, Frederick JM, Zhang K, Brantley MA Jr, Lee AY, Zack DJ, Campochiaro P, Ripke S, Smith RT, Barile GR, Katsanis N, Allikmets R, Daly MJ, Seddon M: Genomewide association study of advanced age-related macular degeneration identifies a role of the hepatic lipase gene (LIPC). Proceedings of the National Academy of Sciences 2010, 107:7395-7400.

80. Tserentsoodol N, Gordiyenko NV, Pascual I, Lee JW, Fliesler SJ, Rodriguez IR: Intraretinal lipid transport is dependent on high density lipoprotein-like particles and class B scavenger receptors. Mol Vis 2006, 12:1319-1333.

81. Duncan KG, Hosseini K, Bailey KR, Yang H, Lowe RJ, Matthes MT, Kane JP, LaVail MM, Schwartz DM, Duncan JL: Expression of reverse cholesterol transport proteins ATP-binding cassette A1 (ABCA1) and scavenger receptor $\mathrm{BI}(\mathrm{SR}-\mathrm{BI})$ in the retina and retinal pigment epithelium. $\mathrm{Br}$ J Ophthalmol 2009, 93:1116-1120.

82. Bjorkhem I, Cedazo-Minguez A, Leoni V, Meaney S: Oxysterols and neurodegenerative diseases. Molecular Aspects of Medicine 2009, 30:171-179.
83. Mast N, Reem R, Bederman I, Huang S, Dipatre PL, Bjorkhem I, Pikuleva IA: Cholestenoic Acid is an important elimination product of cholesterol in the retina: comparison of retinal cholesterol metabolism with that in the brain. Invest Ophthalmol Vis Sci 2011, 52:594-603.

84. Fliesler SJ, Bretillon L: The ins and outs of cholesterol in the vertebrate retina. Journal of Lipid Research 2010, 51:3399-3413.

85. Vejux A, Malvitte L, Lizard G: Side effects of oxysterols: cytotoxicity, oxidation, inflammation, and phospholipidosis. Braz J Med Biol Res 2008 , 41:545-556.

\section{Pre-publication history}

The pre-publication history for this paper can be accessed here: http://www.biomedcentral.com/1471-2415/11/22/prepub

doi:10.1186/1471-2415-11-22

Cite this article as: Dasari et al:: Cholesterol-enriched diet causes agerelated macular degeneration-like pathology in rabbit retina. BMC Ophthalmology 2011 11:22.

\section{Submit your next manuscript to BioMed Central and take full advantage of:}

- Convenient online submission

- Thorough peer review

- No space constraints or color figure charges

- Immediate publication on acceptance

- Inclusion in PubMed, CAS, Scopus and Google Scholar

- Research which is freely available for redistribution

Submit your manuscript at www.biomedcentral.com/submit
Ciomed Central 